\title{
The variable impact of ENSO events on regional dengue/DHF in Indonesia
}

\author{
Paula Arcari ${ }^{1}$ and Nigel Tapper ${ }^{2}$ \\ ${ }^{1}$ School of Global, Urban and Social Studies, RMIT University, Melbourne, Australia \\ ${ }^{2}$ School of Geography and Environmental Sciences, Monash University, Melbourne, Australia \\ Correspondence: Paula Arcari (email: paula.arcari@rmit.edu.au)
}

\begin{abstract}
Although studies have demonstrated significant associations between ENSO events and dengue fever, few have explored regional impacts on dengue fever of separate events. This study explores the impacts of two ENSO events on regional patterns of dengue/ dengue haemorrhagic fever (DHF) incidence in Indonesia. Data consist of monthly cases of dengue/DHF from 1992 to 2001 for each of Indonesia's 27 provinces, and monthly figures for rainfall, rainfall anomalies, temperature, relative humidity and the Southern Oscillation Index (SOI). We conducted Pearson correlation analyses for each independent variable against dengue/DHF incidence, using a direct month-by-month correlation and applying a lag of between one and six months to each variable with respect to dengue/DHF incidence. Based on the SOI value, we identified two ENSO events between 1992 and 2001. To explore each event, we created two dummy variables and in regression analyses for eight provinces. The variance of between 12.9 per cent and 24.5 per cent in provincial dengue/DHF incidence is explained by two or three climate variables in each of the provinces $(p<0.01$ to 0.1$)$. During the 1997/98 event, the explained variance increased by between 7 per cent and 15 per cent in provinces whose climate regimes were most affected by this event. This study demonstrates that indicators of ENSO such as the SOI may assist in the forecast of potential dengue/DHF incidence and distribution in Indonesia.
\end{abstract}

Keywords: dengue fever, ENSO, humidity, Indonesia, rainfall, SOI, temperature

\section{Introduction}

We are currently experiencing a series of the warmest years since records began in 1880 , and 2016 is on track to be the warmest year yet, even after the effects of the recent El Nino, which emerged in early 2015, have subsided (Arndt, 2015; NASA 2016). The frequency, persistence and intensity of the El Nino Southern Oscillation (ENSO), affecting regional variations in precipitation and temperature in the tropics and subtropics, have increased since the 1970s compared with the previous 100 years (Intergovernmental Panel on Climate Change, 2001). As predicted by National Oceanic and Atmospheric Administration's Climate Prediction Centre, the recent event persisted through early 2016 to become a so-called Super El Nino on par with that of 1997-98 and, including that in 1982-83, stands among the three strongest El Nino events on record since 1950 (Halpert, quoted in The Weather Network, 2015; NOAA 2016).

In the last decade, increasing attention has focused on associations between ENSO events or El Nino and a variety of human health problems including vector-borne diseases such as dengue fever (Glantz, 1996; McMichael et al., 1996; Epstein, 1999; Kirono \& Tapper, 1999a; Kovats et al., 2003; Hu et al., 2004; Marlier et al., 2013). The World Health Organization (WHO) describes dengue fever as a major public health problem (category A) and acknowledges it as one of the most significant arboviral infectious diseases that affects 50-100 million people each year. Because of misdiagnosis and underreporting, this figure could be up to four times higher (WHO, 1993; 2009; Murray et al., 2013). Temperature and rainfall together can play significant roles in the life cycle 
of the dengue vector. Additionally, development of the dengue virus, both in the mosquito vector and human host, and biting and breeding rates of the adult mosquitoes accelerate under elevated temperatures (Rodhain \& Rosen, 1997; Gubler, 1998; Gubler \& Meltzer, 1999; Keating, 2001).

Studies in Indonesia, Hawaii, Colombia, French Guiana, the Caribbean, the Pacific Islands and Mexico demonstrate significant associations between ENSO events and dengue fever (Hales et al., 1996; Poveda et al., 2000; Corwin et al., 2001; Gagnon et al., 2001; Gubler DJ, pers. comm., email message to author, 2003; Amarakoon et al., 2007, HurtadoDiaz et al., 2007; Kolivras, 2010). In all but one of these studies, the dengue data are aggregated annually and/or nationally. The exception is the study by Corwin et al. (2001), which focuses on one epidemic period in one Indonesian city. Only two studies use the Southern Oscillation Index (SOI) as a direct indicator of the ENSO event, while the remaining three assign non-numeric markers, i.e., El Nino +1 . Ascribing one measure to all ENSO ${ }^{1}$ events assumes that there is a 'standard'. However, this is definitely not the case (NOAA, 2006; 2016). Each ENSO event differs, sometimes quite dramatically, in duration, intensity and the nature of its climatic implications. Especially intense events are followed by a La Nina phase characterized in the Western Pacific region by excess rainfall, in contrast to the rainfall deficit commonly associated with the El Nino phase. Numeric variables of ENSO, such as the SOI, can provide an indication of the duration and intensity of each phase of these events and are therefore more appropriate for investigating their impact. Hence, this paper aims to address the shortfall perceived in previous studies by considering the varying regional impacts of two ENSO events and the associated variation in regional patterns of dengue/ dengue haemorrhagic fever (DHF) incidence under a range of climatic and environmental situations.

\section{Materials and methods}

Monthly cases of DHF from 1992 to 2001 for each of Indonesia's 27 provinces were supplied by the Indonesian Ministry of Health $(\mathrm{MoH})$. This period was chosen, because data are available for that period and that decade has two significant El Nino/La Nina events. All cases in Indonesia are diagnosed according to WHO guidelines and the same data are used by WHO to compile their country reports. According to a representative from the Indonesian Ministry of Health (Rita Kusriastuti, pers. comm., email message to author, 2003), these data are known to include a number of classic dengue cases, because of differences in diagnostic criteria applied by physicians and rural health workers throughout the country (Rita Kusriastuti, a representative from Indonesian Ministry of Health, pers. comm., email message to author, 2003). This limitation is assumed for the purposes of this study, not to significantly affect or skew the data and its emerging patterns. It is also assumed that any overreporting of the DHF situation is offset by the considerable underreporting, which most authors agree is commonplace in disease statistics especially in developing countries (Monath, 1995; WHO, 2009). For these reasons, this study considers the MoH DHF data to be indicative of dengue/DHF incidence. From these data, mean yearly incidence rates for each province were calculated, categorized and mapped, as shown in Figure 1.

Monthly rainfall data from 1992 to 1999 were supplied by Kirono (2000) and supplemented for the years 2000 and 2001 by Mulyono Prabowo of the Indonesian Bureau of Meteorology. These data were used to create a fourth variable for each province depicting monthly rainfall anomalies (the amount by which each month's rainfall is above or below a defined average), based on the 10-year month-by-month average. 


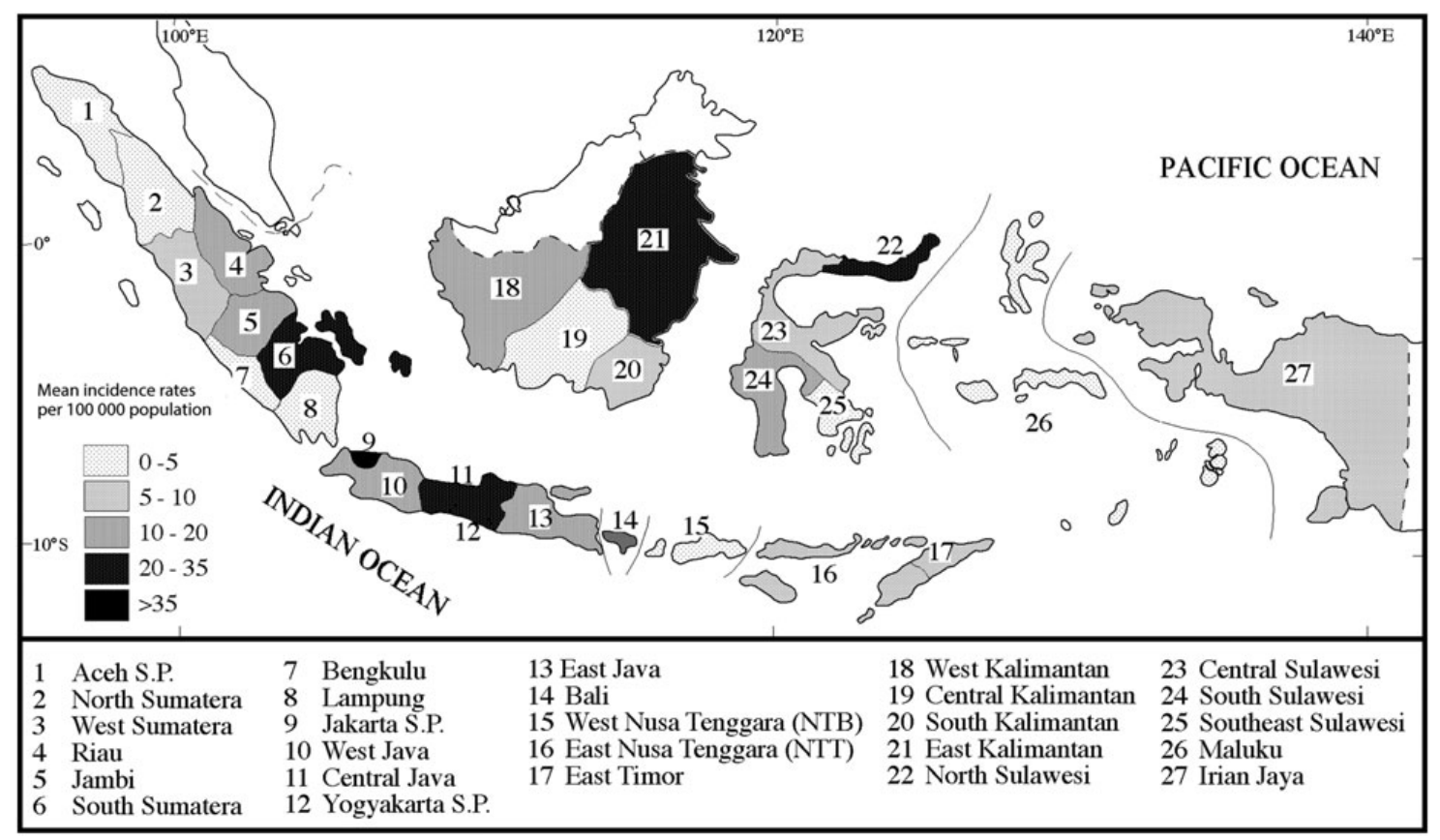

Figure 1. Mean yearly provincial dengue/DHF incidence rates per 100 000, based on a 8 to 10-year period from 1992-2001.

Sources: Indonesian Ministry of Health (data); Kirono, 2000 (basemap).

Indonesia's rainfall is characterized by substantial seasonal and regional variability, a pattern that is exacerbated by ENSO climate variability (Kirono \& Tapper, 1999b). Many regions, especially in the south and east, experience intense seasonal drought during the Austral winter (dry season), but at other times of the year flooding rains can occur across large areas of the country.

Monthly temperature and relative humidity data (the ratio of the actual moisture content of the atmosphere as compared to the maximum that can be held for a given temperature) for the same 10-year period were derived from NCEP/NCAR (National Centers for Environmental Prediction/ National Center for Atmospheric Research) data, which were provided by the NOAA-CIRES Climate Diagnostics Center, Boulder, Colorado. Average daily temperatures across Indonesia do not vary significantly, generally remaining between $23^{\circ} \mathrm{C}$ and $28^{\circ} \mathrm{C}$ (Kuipers, 1993). Depending on altitude and geographic location, regional temperatures can range from a minimum of $19^{\circ} \mathrm{C}$ to a maximum of $35^{\circ} \mathrm{C}$. Relative humidity in Indonesia is consistently high, averaging between 70 and 80 per cent. Regionally, levels rarely fall below 63 per cent, while values above 90 per cent occur fairly regularly (Asian Development Bank, 1994).

Between 1992 and 2001, two significant El Nino Southern Oscillation or ENSO events occurred in 1992-1995 and 1997-1998. The SOI was used to monitor the development and movement of the ENSO phenomenon and presented in the form of monthly anomalies. Monthly SOI values for the relevant 10 -year period were obtained from the Australian Bureau of Meteorology's website (n.d.).

Since it was not practical to carry out a detailed investigation of all 27 provinces, a regional focus was adopted through the selection of eight provinces based on their varying characteristics with regard to climate, pattern of dengue/DHF incidence and population density. To ensure that the chosen provinces were appropriately disparate in terms of dengue/DHF and demographic characteristics, the selection process took into account characteristic features of provincial dengue/DHF incidence profiles, mean and maximum 
yearly incidence rates for each province, provincial population densities and results of a spatial autocorrelation analysis. In addition, the following four selection criteria were observed to accommodate the full range of dengue/DHF situations.

1. Provinces represented each of Indonesia's five climatic regions identified by Kirono (2000).

2. Their dengue/DHF incidence profiles were different yet representative of temporal characteristics shared by more than one province.

3. They were representative of different combinations of various provincial population densities and mean and maximum yearly incidence rates.

4. If their patterns of dengue/DHF incidence were highly correlated, the provinces were deemed sufficiently different from each other in at least one other respect —either population density, mean and maximum yearly incidence rate or intensity of incidence.

On these bases, five provinces (East Kalimantan, West Kalimantan, Central Sulawesi, Central Java and Maluku) and three outliers (Aceh, West Nusa Tenggara and Jakarta) were selected (see Arcari et al., 2007 for a full description of this selection process).

Two phases of statistical analysis were used to explore associations between the five independent variables (rainfall, rainfall anomalies, temperature, relative humidity and the SOI) and the dependent variable (dengue/DHF incidence rates). First, a Pearson correlation analysis (significance level 95 per cent) was conducted for each independent variable against dengue/DHF incidence. In addition to a direct month-by-month correlation, each variable was lagged between one and six months, with respect to dengue/DHF incidence. Second, a series of stepwise multiple regression analyses that used all five independent variables were conducted using a basic unlagged dataset for each province and a second dataset that incorporated the most significant lag for each variable according to the initial Pearson correlation analysis (see Arcari et al., 2007 for a full description and explanation of these methods). The final results of the provincial analyses from this paper summarized in Table 1 provide a basis against which to compare the outcomes of the ENSO analyses, which are the subject of this paper. The two sets of regression analyses are referred to as either non-ENSO or ENSO (ENSOI and ENSO2), to be distinguished from each other. Only the results of the optimal regression models for each province, i.e., those that explained the most variance in dengue/DHF incidence, were included in the analysis.

\section{The ENSO analysis}

In order for the researchers to conduct a statistical analysis of the impact of the 1992-95 and 1997-98 ENSO events on dengue/DHF incidence, each event has to be defined. While acknowledging the different methods used to define ENSO events (Ropelewski $\delta$ Halpert, 1987; Trenberth \& Hoar, 1996; Chiew et al., 1998; Kiladis \& van Loon, 1988; Gagnon et al., 2001), this study recognizes that 'the definition is still evolving and...needs to recognize the richness of the phenomenon' (Trenberth, 1997). Following Woodruff and Guest's (2000) recommendation to establish measures of relevance for individual regions, this study adopts a unique definition of ENSO events specific to Indonesia.

An SOI value of two was set as the upper limit for the event. Anything above this value would not be considered an ENSO month. Thus the first event (ENSO1) was defined as lasting from January 1992 to February 1995 (38 consecutive months), and the second event (ENSO2) from March 1997 to April 1998 (14 consecutive months). According to this criterion, the length of each event according will influence the results of the regression analyses, there being 24 more months of data to associate with dengue/DHF incidence in the first event. However, the intention is to explore each event according to its individual characteristics, not according to a homogeneous definition of these 
Table 1. Non-ENSO multiple regression results for each province $(p<0.1)$. The direction and magnitude of the association, according to the unstandardized B coefficient, are indicated by the sign. The relative importance of each variable, according to the standardized B coefficient, is given in brackets, with 1 being the most important. The lags that produced the optimal model are provided in the last column.

\begin{tabular}{|c|c|c|c|c|c|c|}
\hline Province & Rainfall & $\begin{array}{c}\text { Rainfall } \\
\text { Anomalies } \\
\text { (Anom.) }\end{array}$ & $\begin{array}{l}\text { Temperature } \\
\text { (Temp.) }\end{array}$ & $\begin{array}{l}\text { Humidity } \\
\text { (Hum.) }\end{array}$ & SOI & Lags \\
\hline West Kalimantan & & & $++(1)$ & $-(2)$ & & $\begin{array}{l}\text { Temp.: } 0 \text { months } \\
\text { Anom.: } 0 \text { months } \\
\text { Rainfall: } 3 \text { months } \\
\text { SOI: } 0 \text { months } \\
\text { Hum.: } 2 \text { months }\end{array}$ \\
\hline East Kalimantan & & $-(2)$ & $++(1)$ & & & $\begin{array}{l}\text { Temp.: } 0 \text { months } \\
\text { Anom.: } 1 \text { month } \\
\text { Rainfall: } 1 \text { month } \\
\text { SOI: } 0 \text { months } \\
\text { Hum.: } 4 \text { months }\end{array}$ \\
\hline Central Java & $+(1)$ & $-(2)$ & & & & No Lags \\
\hline Aceh & $+(1)$ & & $+(3)$ & & $-(2)$ & $\begin{array}{l}\text { Temp.: } 0 \text { months } \\
\text { Anom.: } 0 \text { months } \\
\text { Rainfall: } 0 \text { months } \\
\text { SOI: } 1 \text { month } \\
\text { Hum.: } 0 \text { months }\end{array}$ \\
\hline Jakarta & $+(2)$ & & $++++(1)$ & & $-(3)$ & $\begin{array}{l}\text { Temp.: } 1 \text { month } \\
\text { Anom.: } 3 \text { months } \\
\text { Rainfall: } 2 \text { months } \\
\text { SOI: } 0 \text { months } \\
\text { Hum.: } 0 \text { months }\end{array}$ \\
\hline Central Sulawesi & & $+(3)$ & $+(1)$ & & $-(2)$ & $\begin{array}{l}\text { Temp.: } 3 \text { months } \\
\text { Anom.: } 0 \text { months } \\
\text { Rainfall: } 0 \text { months } \\
\text { SOI: } 5 \text { months } \\
\text { Hum.: } 0 \text { months }\end{array}$ \\
\hline Maluku & & & $+(1)$ & $+(3)$ & $-(2)$ & $\begin{array}{l}\text { Temp.: } 0 \text { months } \\
\text { Anom.: } 3 \text { months } \\
\text { Rainfall: } 0 \text { months } \\
\text { SOI: } 1 \text { month } \\
\text { Hum.: } 0 \text { months }\end{array}$ \\
\hline $\begin{array}{l}\text { West Nusa } \\
\text { Tenggara }\end{array}$ & & & $+(1)$ & $+(3)$ & $-(2)$ & $\begin{array}{l}\text { Temp.: } 0 \text { months } \\
\text { Anom.: } 0 \text { months } \\
\text { Rainfall: } 0 \text { months } \\
\text { SOI: } 1 \text { month } \\
\text { Hum.: } 0 \text { months }\end{array}$ \\
\hline
\end{tabular}

For each unit change in the independent variable, the magnitude of change in dengue/DHF incidence rates is indicated as follows.

$<$ l case per 100 000: + or -

2 to 3.99 cases per $100000:+++$ or ---

1 to 1.99 cases per $100000:++$ or --

$>4$ cases per $100000:++++$ or ----

events, which, as illustrated previously, has been considered impractical by at least one author. The length of the event, as well as its climatic impacts, may have an impact on dengue/DHF incidence, and this factor was taken into consideration when the researchers decided to maintain the different durations of each event. However this method does not recognize the different intensities of each event, with SOI values of 
between -25 and +2 over the 38 months of ENSOl (1992-95) and between -28 and -8 over the 14 months of ENSO2 (1997-98) (Figure 2). This shortcoming provides an opportunity for a third phase of statistical analysis and, while not investigated here, is acknowledged as a potential factor during the analysis of the results.

The creation of a 'dummy' variable allows the effect of this variable on the dependent variable to be investigated and quantified in what is called a dummy regression analysis (Gujarati, 1995; de Vaus, 2002). Over the 10 years of the study period, each ENSO event is either present or absent. If it is present during any given month, ' 1 ' is entered into the appropriate cell, if absent, ' 0 ' is entered. In this way, an ENSO variable is created for each event. From this dummy variable, five additional variables are created from the multiplication of the ENSO variable with each climate variable in turn. The resulting variables provide a representation of the behaviour of each climate variable during the ENSO period only, with the rest of the dataset consisting of zeros; no ENSO event in any given month means no value for that month.

For each province, the preliminary regression analyses are termed non-ENSO, and the subsequent dummy regression analyses are termed ENSO1 and ENSO2. Because the ENSO event data are not extracted from the non-ENSO analyses, any associations specific to these periods are included in the overall signal. However, as this is a preliminary investigation, this method is considered to provide a sufficient measure of changes in the direction and/or magnitude of the associations between the variables specifically during ENSO periods. If the results prove significantly different at this level, subsequent analyses may benefit from isolating non-ENSO from ENSO periods for a more accurate calculation of the differences.

As with the non-ENSO multiple regression analyses, both unlagged and lagged datasets for each variable were used to conduct the dummy regression analyses. The analyses allow a provisional comparison on the effectiveness of the Pearson correlations, which use the full 10-year datasets, in explaining the behaviour of each variable during the ENSO periods alone. Although not a rigorous test, the comparison at least prevents the statistical assumptions concerning the most significant lag, made on the basis of the 10-year Pearson correlations, from being applied perhaps incorrectly to these two individual points in time. A thorough comparison of the $\mathrm{R}^{2}$ values (explained variance), $\mathrm{B}$ coefficients (magnitude of association) and significance levels resulting from models using various lags indicate the most appropriate model during each ENSO event.

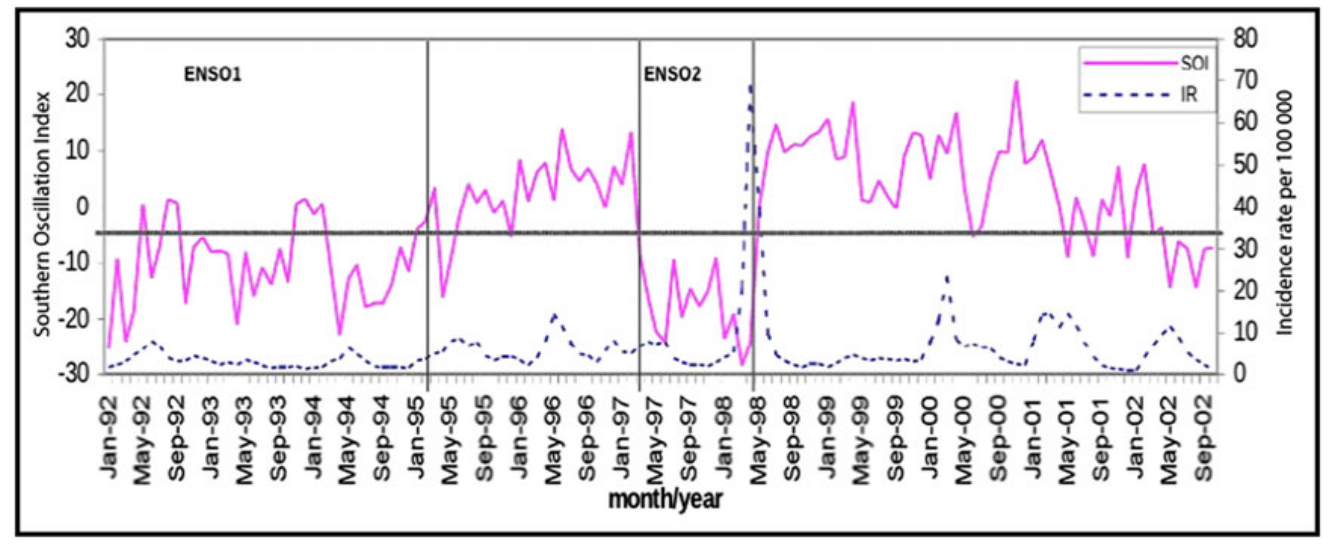

Figure 2. Mean monthly dengue/DHF incidence rates and monthly SOI values in Jakarta from 1992-2001. Sources: Indonesian $\mathrm{MoH}$ and Australian Bureau of Meteorology (n.d.). 
Multicollinearity between the climate variables is an inherent opportunity for misrepresentation, as certain results may reflect a surrogate correlation. Nevertheless, the strength of associations and repetition of certain signals will be taken as sufficient evidence that results are significant, within the inherent limitations of the statistical procedures.

\section{Results}

According to the data for 1992-2001, Jakarta exhibits the highest number of cases and highest dengue/DHF incidence rates of the eight provinces. Karyanti et al. (2014) similarly note that between 2010 and 2013, the highest incidence of DHF occurred in Jakarta and Bali, while Kamaruddin and Sungkar (2013: 16) describe DHF as constituting 'a significant public health problem in Jakarta', which has approximately 25 per cent of all diagnosed cases in Indonesia. Consequently, while the results of the ENSO regression analyses for Jakarta are presented in full primarily to illustrate the procedure (Table 3), an increased understanding of incidence dynamics for the most affected province will result in more effective prevention and control. Summarized results for the remaining provinces appear in Tables 3-6, with the non-ENSO analyses presented in Table 1.

\section{Jakarta}

The Pearson correlation values for Jakarta, for each of the five climate variables lagged 06 months, indicate a need for two sets of lagged variables to fully explore the suggested associations (see Arcari et al., 2007 for details). Hence three datasets were used for the regression analyses, Datasets A, B and C (Table 2).

The non-ENSO multiple regression analyses reported in Arcari et al. (2007) reveals that Dataset B produced the optimal model, with the adjusted $\mathrm{R}^{2}$ value showing that 24.5 per cent of the variance in dengue/DHF incidence from 1992-2001 is explained by three variables, temperature, rainfall and the SOI $(\mathrm{p}<0.1)$. The models using Datasets A and C explain 17.7 per cent and 18.7 per cent respectively. Of the three predictors in the optimal model, temperature is associated with the greatest magnitude of standardized change in dengue/DHF incidence, followed by rainfall and then the SOI. This change amounts to an increase in dengue/DHF incidence of 4.84 cases per 100000 for every $1^{\circ} \mathrm{C}$ increase in temperature, 0.015 cases per 100000 for every increase in rainfall of $1 \mathrm{~mm}$ and 0.109 cases per 100000 for every one unit decrease in the value of the SOI (see Arcari et al., 2007 for full results and explanation).

Table 3 shows the results of the ENSO1 and ENSO2 dummy multiple regression analyses for each variable. As there is no change in the lags used for humidity, rainfall anomalies and the SOI between Datasets B and C, the percentage variance explained by these variables during both events is the same. However, during ENSO2, there is an increase of

Table 2. Summary of datasets used in regression analyses.

\begin{tabular}{llc}
\hline Unlagged & \multicolumn{2}{c}{ Dataset A } \\
\cline { 2 - 3 } Lagged & Dataset B & Dataset C \\
\hline Temperature & 1 month & 0 months \\
Rainfall & 2 months & 1 month \\
Humidity & 0 months & 0 months \\
Rainfall Anomalies & 3 months & 3 months \\
SOI & 0 months & 0 months
\end{tabular}




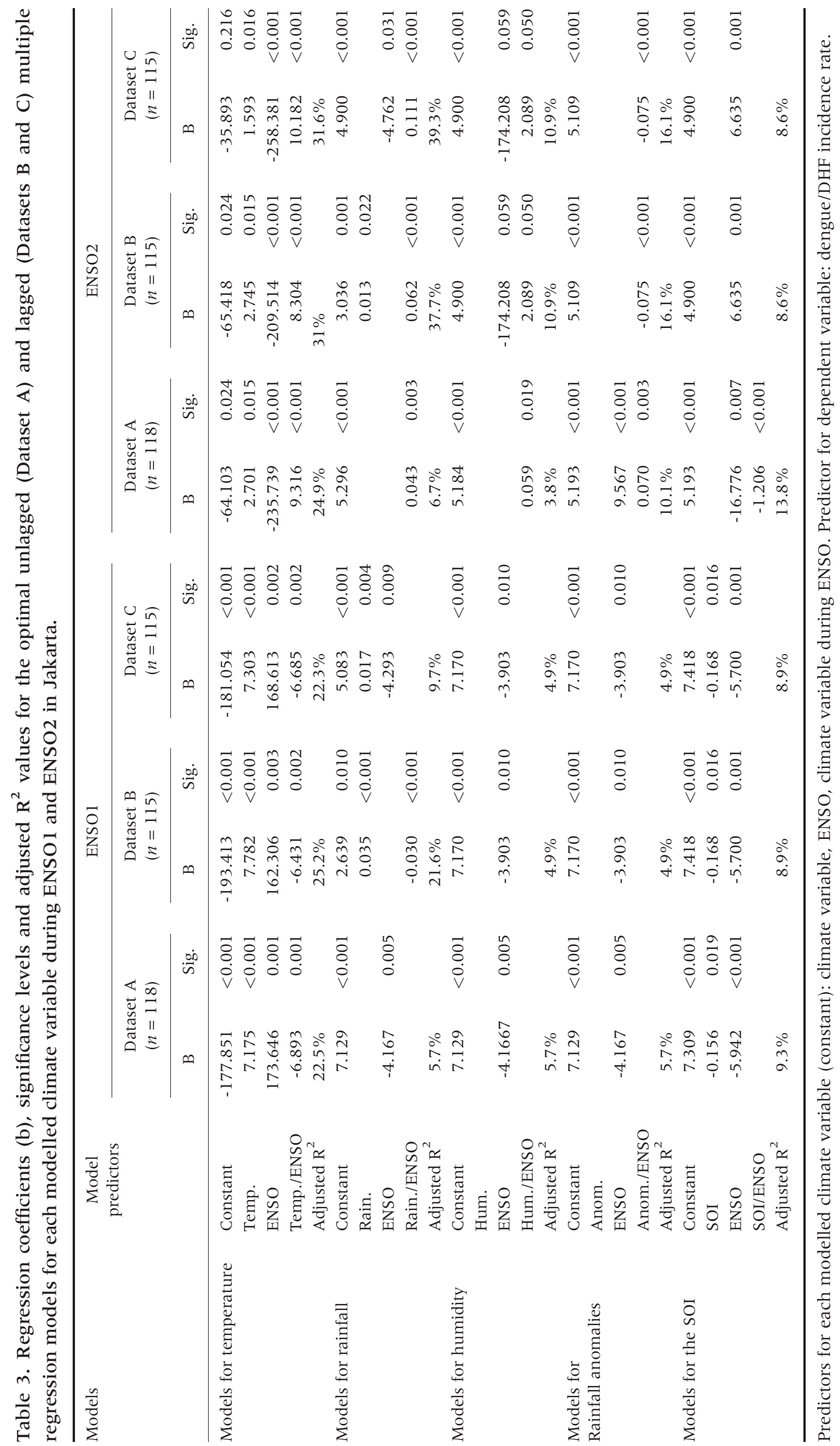


7.1 per cent and 6 per cent respectively in the Dataset B and C models for humidity and rainfall anomalies as compared with ENSO 1. A slight decrease might have been expected (as seen for the SOI) as a result of the smaller sample size. Therefore, some aspect of this second event increased the magnitude of the association of dengue/DHF incidence with humidity and rainfall anomalies. This magnitude perhaps indicates the greater intensity of this shorter event, although further investigation would be required to clarify the meaning and relevance of this observation.

An overview of the ENSO results for Jakarta (Table 3) shows that during the first event, ENSO1, the Dataset B modelled variables explain the greatest amount of cumulative variance $\left(\mathrm{R}^{2}\right)$ in dengue/DHF incidence. In particular, when lagged by two months (Dataset B) as opposed to zero (Dataset A) or one month (Dataset C), the rainfall model respectively explains 15.9 per cent and 11.9 per cent more variance. In the models for humidity and rainfall anomalies for all three datasets, only the ENSOl event itself (ENSO) appears as a significant predictor, suggesting that both these climate variables are not significant for dengue/DHF incidence at this time. The SOI models explain a fairly consistent amount of variance across all three datasets. However, the value of the SOI during the ENSOl event itself (SOI/ENSO) does not appear any more significant for dengue/DHF incidence at this time than at any other time over the 10 years. Rainfall and temperature together explain the greatest amount of variance during this event. During ENSO2, the Dataset C models explain slightly more variance in dengue/DHF incidence. This increase over Dataset B is seen in the temperature model (0.6 per cent) and the rainfall model ( 1.6 per cent). The variance for humidity, rainfall anomalies and the SOI remains constant in both lagged models-Datasets B and C. Once again, the temperature and rainfall models explain the greatest amount of variance in the two lagged models. The number of significant predictors for these variables in each lagged model is the same. However, when rainfall is lagged by two months (Dataset B) as opposed to one (Dataset $\mathrm{C}$ ), the magnitude of the association with rainfall during the event (Rain/ENSO) decreases slightly, while rainfall over the 10-year period (Rain) appears for the first time as a significant predictor during ENSO2. Table 3 shows that these five climate variables explain significantly more variance in dengue/DHF incidence during ENSO2 than ENSO1. However, temperature and lagged rainfall more consistently explain a greater amount of variance in both events. The following two sections describe the results for each event in more detail.

ENSO1. In the models for temperature during ENSO1, the generally positive association between dengue/DHF incidence and temperature (Temp.), which is also apparent in the non-ENSO regression (Table 1), is almost nullified by temperature specifically during this event (Temp/ENSO). In the non-ENSO results (Table 1), a $1{ }^{\circ} \mathrm{C}$ increase in temperature is associated with an increase in incidence rates of 4.84 cases per 100000 . However, during the ENSOl period alone, an increase of between 7.175 cases per 100000 for Dataset $\mathrm{A}$ and 7.782 (1) cases per 100000 (for every $1{ }^{\circ} \mathrm{C}$ increase in temperature) for Dataset B (Temp.) is countered by the effect of temperature specifically at this time (Temp/ENSO), which reduces the positive association by -6.893 and -6.431 cases per 100000 respectively. The net outcome is still a slight positive association, but the magnitude of the impact of increasing temperatures on dengue/DHF incidence rates at this time is greatly reduced. Rainfall (Rain) also generally shows a positive association with dengue/DHF incidence. However, when rainfall is lagged by two months in the ENSOl Dataset B model, this association diminishes by the value of this variable during the event itself (Rain/ENSO). Again the net outcome is still positive, but the 
magnitude of the association is reduced from 0.035 cases per 100000 for every $1 \mathrm{~mm}$ increase in rainfall to 0.005 (-0.030 for Rain/ENSO). In the models for humidity and rainfall anomalies, the predictors for the actual variables (Hum; Hum/ENSO; Anom; Anom/ENSO) are not significant for dengue/DHF incidence at this time. Only the predictor for the event itself (ENSO) appears in the output models for these variables. The SOI for the whole 10-year period (SOI) exhibits a negative association with dengue/DHF incidence across all three datasets $(\mathrm{p}<0.05)$. The SOI specifically during the event (SOI/ENSO) is not significant in comparison to all other times, while the event itself (ENSO) is negatively associated with dengue/DHF incidence.

ENSO2. The ENSO2 models illustrate the very different nature of this particular event. The temperature models for each dataset again show a positive, though lower, association between dengue/DHF incidence and temperature throughout the 10-year period (Temp.), as compared with ENSOl. However, this association is greatly enhanced, rather than diminished, by the magnitude of the association with temperature specifically during the event (Temp/ENSO)—an additional 8 to 10 cases for every increase of $1{ }^{\circ} \mathrm{C}$. In the rainfall models, rainfall (Rain) shows a significant positive association with dengue/DHF incidence rates only when lagged by two months (Dataset B: $\mathrm{p}<0.05)$. However, during the event (Rain/ENSO), this variable becomes significant across all three modelled datasets, though once again, with a greater impact on dengue/DHF incidence when lagged by two months (Dataset B: $\mathrm{p}<0.05$ ). The 10-year values of humidity (Hum.), rainfall anomalies (Anom.) and the SOI are not significant for dengue/DHF incidence in any dataset models for the second event. During the event, humidity demonstrates a positive association across all three datasets (Hum/ENSO: $\mathrm{p}<0.05$ ), the variable rainfall anomalies (Anom/ENSO) demonstrates a positive, unlagged association (Dataset $\mathrm{A}: \mathrm{p}<0.01$ ) and a negative lagged association (Datasets $\mathrm{B}$ and $\mathrm{C}: \mathrm{p}<0.01$ ), and finally the SOI (SOI/ENSO) demonstrates a negative association only in the unlagged model (Dataset $\mathrm{A}: \mathrm{p}<0.01$ ). In the two lagged models (Datasets $\mathrm{B}$ and $\mathrm{C}$ ), the SOI values during the event (SOI/ ENSO) are not significant, while the magnitude of the impact on dengue/DHF incidence of the ENSO event itself $($ ENSO) is greatly enhanced $(\mathrm{p}<0.01)$. Evidently, the lagging procedure, involving a three-month extension of this event (via the threemonth lag in rainfall anomalies) has allowed some other aspect of the ENSO event to emerge as more significant for dengue/DHF incidence than the SOI values, despite a clear visual association between the negative SOI values at this time and a dramatic increase in the incidence of dengue/DHF (Figure 3). This finding tallies with the results

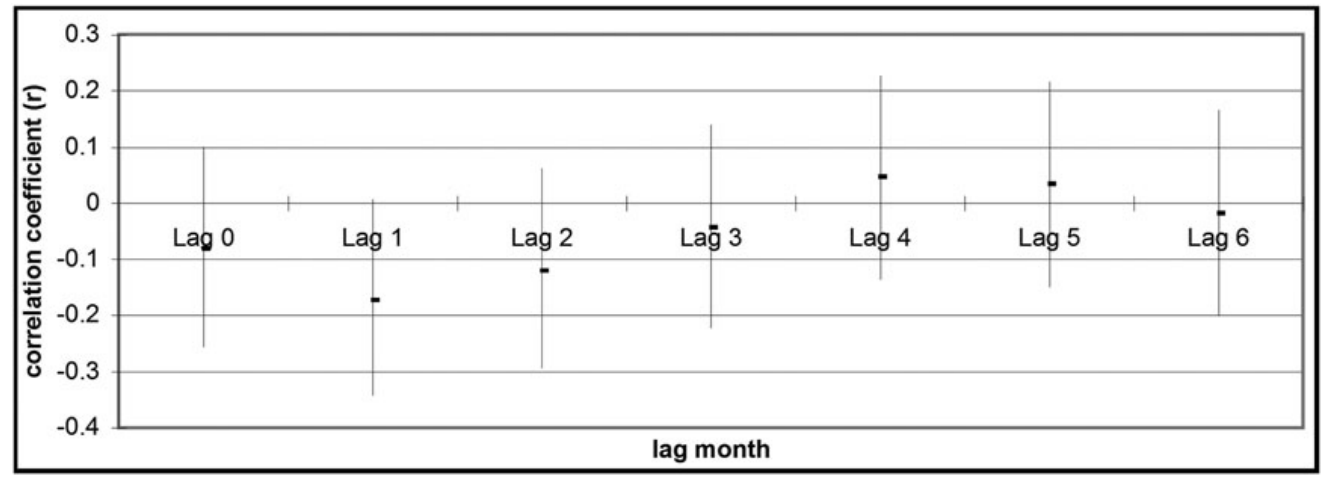

Figure 3. Pearson correlation analysis, with 95 per cent confidence intervals, between mean monthly denguel DHF incidence rates and the SOI in Jakarta from 1992-2001. Sample size $(n)=115-121$. 


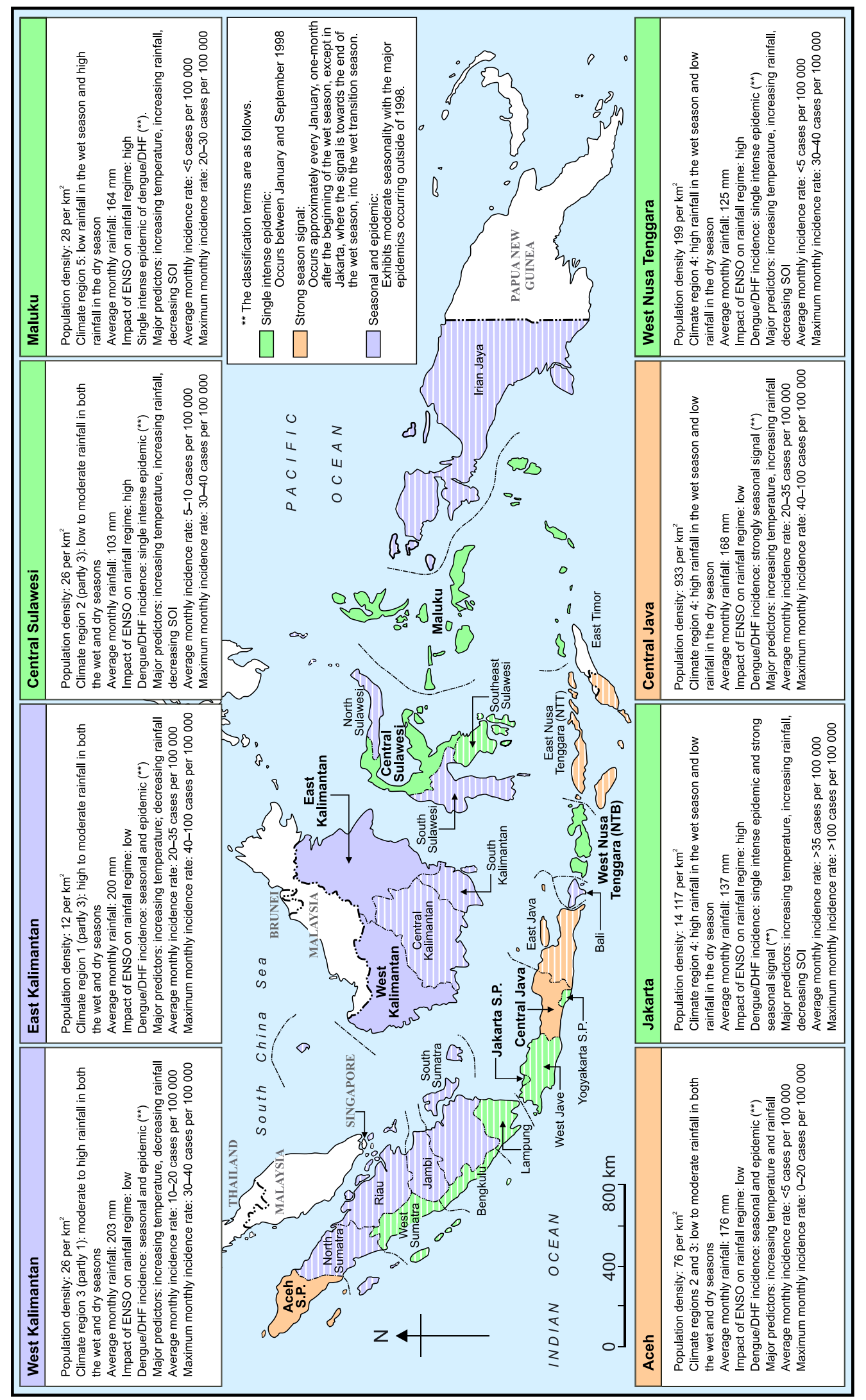

ธั

ङ

$\frac{5}{5}$

$2 \frac{1}{2}$

:

章

है

:ुँ

है

空茖

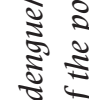

: త్ర

ํำ

के

के

ปี

ว

ㄱํㄱ.

ริ

$5 \frac{y}{5}$

密 :

$\frac{\hat{3}}{0}$

\%

i

产

*

㲾

s.

:

ป

:

ㄴำ

₹

5

ญ

ปิ)

.

荧

ป 
of the Pearson correlations (Figure 4) and may be explained by the association of regular, though less dramatic, seasonal increases in dengue/DHF incidence with both high and low SOI values throughout the 10-year period. These associations are likely to diminish the significance of the SOI during this one event. The principle trends seen during this event are that associations between dengue/DHF incidence and each climate variable are enhanced, particularly for temperature. These associations are strongest when rainfall anomalies are lagged by three months and rainfall by either one or two months. A comparison of the two events based on the above results indicates that the shorter, more intense ENSO2 event is significantly associated with increased rates of dengue incidence, while the longer, less intense ENSOl event, had the opposite effect, compared with the 10-year non-ENSO regression analysis.

\section{Summary of provincial results}

The same statistical analyses were performed for all eight provinces. The summarized results of the non-ENSO, ENSO1 and ENSO2 analyses appear in Tables 1, 4 and 5 respectively. In the non-ENSO results table, the lag times for each variable corresponding to the optimal model are shown in the last column. The results for the ENSO1 and ENSO2 dummy regression analyses indicate in what way, if any, the associations between the variables during these events are different from those observed over the entire 10-year (non-ENSO) period. Compared with the results of the non-ENSO analyses, associations between dengue/DHF incidence and any one climate variable during ENSO1 and ENSO2 may be enhanced $(\uparrow)$, diminished $(\downarrow)$, cancelled to 'no significance' after being previously significant $(\varnothing)$, reversed $(\leftrightarrow)$ or unchanged (zero/capital O). Table 1 shows that temperature is a significant predictor of variations in dengue/DHF incidence in seven of the eight provinces. The SOI appears in five, followed by rainfall, rainfall anomalies and humidity in three provinces each. The associations with temperature are consistently positive, while those with the SOI are consistently negative. All associations with rainfall are positive, although Central Java and East Kalimantan exhibit significant negative associations with rainfall anomalies. In descending order of relative importance, temperature, rainfall and the SOI exhibit the most significant statistical associations with dengue/DHF incidence in these eight provinces. Based on these results, three groups of provinces were identified (Arcari et al., 2007): Central Sulawesi, Maluku, West Nusa Tenggara and Jakarta; Aceh and Central Java; and West and East Kalimantan.

Tables 4 and 5 summarize the associations between the variables in each province during ENSO1 and ENSO2. Table 4 shows that in seven of the eight provinces, associations with temperature during ENSOl are diminished, cancelled to 'no significance' or reversed. Central Java, a province without former association with temperature, becomes the only province to exhibit an enhanced association. Central Java is also the only province to develop a positive association with the SOI during this event where formerly there was no association. West and East Kalimantan continue to exhibit no significant associations with the SOI, while in Aceh, the negative association with the SOI, exhibited in the non-ENSO analysis, is unchanged by this event. In West Nusa Tenggara, Central Sulawesi and Maluku, the negative association with the SOI is either diminished or reversed to positive. Only in Jakarta is the negative association with the SOI enhanced. With respect to rainfall, Aceh and Central Sulawesi are the only provinces to show an enhanced positive association with rainfall and rainfall anomalies. Thus, the results for this event show less distinction among the provinces, although West and East Kalimantan and Central Java still appear to behave differently in certain respects. 
Table 4. ENSO1 multiple regression results for each province. The direction and magnitude of the association, according to the unstandardized B coefficient, are indicated by the sign. Any change in the relationship between the variables as compared with the non-ENSO regressions, is indicated in brackets. Where no relationship previously existed, there is no bracket. The lags that produced the optimal model are provided in the last column.

\begin{tabular}{|c|c|c|c|c|c|c|}
\hline Province & Rainfall & $\begin{array}{c}\text { Rainfall } \\
\text { anomalies } \\
\text { (Anom.) }\end{array}$ & $\begin{array}{l}\text { Temperature } \\
\text { (Temp.) }\end{array}$ & $\begin{array}{l}\text { Humidity } \\
\text { (Hum.) }\end{array}$ & SOI & Lags \\
\hline West Kalimantan & - & & $-(\leftrightarrow)$ & $-(\downarrow)$ & & $\begin{array}{l}\text { Temp.: } 0 \text { months } \\
\text { Anom.: } 0 \text { months } \\
\text { Rainfall: } 3 \text { months } \\
\text { SOI: } 0 \text { months } \\
\text { Hum.: } 2 \text { months }\end{array}$ \\
\hline East Kalimantan & $\varnothing$ & $+(\leftrightarrow)$ & $+(\downarrow)$ & & & $\begin{array}{l}\text { Temp.: } 0 \text { months } \\
\text { Anom.: } 1 \text { month } \\
\text { Rainfall: } 1 \text { month } \\
\text { SOI: } 0 \text { months } \\
\text { Hum.: } 4 \text { months }\end{array}$ \\
\hline Central Java & $+(\downarrow)$ & $\varnothing$ & + & - & + & $\begin{array}{l}\text { Temp.: } 0 \text { months } \\
\text { Anom.: } 0 \text { months } \\
\text { Rainfall: } 1 \text { month } \\
\text { SOI: } 0 \text { months } \\
\text { Hum.: } 0 \text { months }\end{array}$ \\
\hline Aceh & $+(\uparrow)$ & + & $\varnothing$ & & $-(0)$ & $\begin{array}{l}\text { Temp.: } 0 \text { months } \\
\text { Anom.: } 0 \text { months } \\
\text { Rainfall: } 0 \text { months } \\
\text { SOI: } 1 \text { month } \\
\text { Hum.: } 0 \text { months }\end{array}$ \\
\hline Jakarta & $+(\downarrow)$ & & $++(\downarrow)$ & & $-(\uparrow)$ & $\begin{array}{l}\text { Temp.: } 1 \text { month } \\
\text { Anom.: } 3 \text { months } \\
\text { Rainfall: } 2 \text { months } \\
\text { SOI: } 0 \text { months } \\
\text { Hum.: } 0 \text { months }\end{array}$ \\
\hline Central Sulawesi & + & $+(\uparrow)$ & $+(\downarrow)$ & & $+(\leftrightarrow)$ & $\begin{array}{l}\text { Temp.: } 3 \text { months } \\
\text { Anom.: } 0 \text { months } \\
\text { Rainfall } 0 \text { months } \\
\text { SOI: } 5 \text { months } \\
\text { Hum.: } 0 \text { months }\end{array}$ \\
\hline Maluku & $\varnothing$ & - & $\varnothing$ & $-(\leftrightarrow)$ & $+(\leftrightarrow)$ & $\begin{array}{l}\text { Temp.: } 0 \text { months } \\
\text { Anom.: } 3 \text { months } \\
\text { Rainfall: } 0 \text { months } \\
\text { SOI: } 1 \text { month } \\
\text { Hum.: } 0 \text { months }\end{array}$ \\
\hline $\begin{array}{l}\text { West Nusa } \\
\text { Tenggara }\end{array}$ & & & $+(\downarrow)$ & $\varnothing$ & $-(\downarrow)$ & $\begin{array}{l}\text { Temp.: } 0 \text { months } \\
\text { Anom.: } 0 \text { months } \\
\text { Rainfall: } 0 \text { months } \\
\text { SOI: } 1 \text { month } \\
\text { Hum.: } 0 \text { months }\end{array}$ \\
\hline
\end{tabular}

For each unit change in the independent variable, the magnitude of change in dengue/DHF incidence rates is indicated as follows.

$<$ l case per 100 000: + or -

2 to 3.99 cases per $100000:+++$ or ---

1 to 1.99 cases per $100000:++$ or --

$>4$ cases per $100000:++++$ or ----

Nature of the change in the association between the variables: diminished $(\downarrow)$, enhanced $(\uparrow)$, cancelled to 'no significance' (Ø), reversed $(\leftrightarrow)$ and unchanged $(\mathrm{O})$. 
Table 5. ENSO2 multiple regression results for each province. The direction and strength of the association, according to the unstandardized B coefficient, are indicated by the sign. Any change in the relationship between the variables as compared with the non-ENSO regressions, is indicated in brackets. Where no relationship previously existed, there is no bracket. The lags that produced the optimal model are provided in the last column.

\begin{tabular}{|c|c|c|c|c|c|c|}
\hline Province & Rainfall & $\begin{array}{c}\text { Rainfall } \\
\text { anomalies } \\
\text { (Anom.) }\end{array}$ & $\begin{array}{l}\text { Temperature } \\
\text { (Temp.) }\end{array}$ & $\begin{array}{l}\text { Humidity } \\
\text { (Hum.) }\end{array}$ & SOI & Lags \\
\hline West Kalimantan & - & - & $++(\uparrow)$ & $-(\downarrow)$ & - & $\begin{array}{l}\text { Temp.: } 0 \text { months } \\
\text { Anom.: } 0 \text { months } \\
\text { Rainfall: } 3 \text { months } \\
\text { SOI: } 0 \text { months } \\
\text { Hum.: } 2 \text { months }\end{array}$ \\
\hline East Kalimantan & - & $-(0)$ & $++(\uparrow)$ & & & $\begin{array}{l}\text { Temp.: } 0 \text { months } \\
\text { Anom.: } 1 \text { month } \\
\text { Rainfall: } 1 \text { month } \\
\text { SOI: } 0 \text { months } \\
\text { Hum.: } 4 \text { months }\end{array}$ \\
\hline Central Java & $+(\downarrow)$ & $\varnothing$ & + & & & $\begin{array}{l}\text { Temp.: } 0 \text { months } \\
\text { Anom.: } 0 \text { months } \\
\text { Rainfall: } 1 \text { month } \\
\text { SOI: } 0 \text { months } \\
\text { Hum.: } 0 \text { months }\end{array}$ \\
\hline Aceh & $+(0)$ & + & $\varnothing$ & & $-(0)$ & $\begin{array}{l}\text { Temp.: } 0 \text { months } \\
\text { Anom.: } 0 \text { months } \\
\text { Rainfall: } 0 \text { months } \\
\text { SOI: } 1 \text { month } \\
\text { Hum.: } 0 \text { months }\end{array}$ \\
\hline Jakarta & $+(\uparrow)$ & - & $++++(\uparrow)$ & +++ & $\varnothing$ & $\begin{array}{l}\text { Temp.: } 1 \text { month } \\
\text { Anom.: } 3 \text { months } \\
\text { Rainfall: } 2 \text { months } \\
\text { SOI: } 0 \text { months } \\
\text { Anom.: } 0 \text { months }\end{array}$ \\
\hline Central Sulawesi & + & $+(\uparrow)$ & $+++(\uparrow)$ & + & $-(\uparrow)$ & $\begin{array}{l}\text { Temp.: } 3 \text { months } \\
\text { Anom.: } 0 \text { months } \\
\text { Rainfall: } 0 \text { months } \\
\text { SOI: } 5 \text { months } \\
\text { Hum.: } 0 \text { months }\end{array}$ \\
\hline Maluku & + & + & $++(\uparrow)$ & $+(\uparrow)$ & $-(\uparrow)$ & $\begin{array}{l}\text { Temp.: } 0 \text { months } \\
\text { Anom.: } 0 \text { months } \\
\text { Rainfall: } 0 \text { months } \\
\text { SOI: } 1 \text { month } \\
\text { Hum.: } 0 \text { months }\end{array}$ \\
\hline West Nusa Tenggara & + & + & $++(\uparrow)$ & $\varnothing$ & $-(\uparrow)$ & $\begin{array}{l}\text { Temp.: } 0 \text { months } \\
\text { Anom.: } 0 \text { months } \\
\text { Rainfall: } 0 \text { months } \\
\text { SOI 1: month } \\
\text { Hum.: } 0 \text { months }\end{array}$ \\
\hline
\end{tabular}

For each unit change in the independent variable, the magnitude of change in dengue/DHF incidence rates is indicated as follows.

$<1$ case per 100 000: + or -

2 to 3.99 cases per $100000:+++$ or ---

1 to 1.99 cases per $100000:++$ or --

$>4$ cases per $100000:++++$ or ----

Nature of the change in the association between the variables: diminished $(\downarrow)$, enhanced $(\uparrow)$, cancelled to 'no significance' $(\varnothing)$, reversed $(\leftrightarrow)$ and unchanged $(\mathrm{O})$. 
The second ENSO event portrays a very different picture. As shown in Table 5, every province except Aceh and Central Java exhibits an enhanced positive association with temperature. In Central Java the strength of the positive association with temperature is not affected by this event, while in Aceh the formerly significant positive association is cancelled. With regard to rainfall, formerly positive associations are either unchanged or enhanced, while West and East Kalimantan develop negative associations with both rainfall and rainfall anomalies. Central Java is the only province to exhibit a diminished association with rainfall and rainfall anomalies. Central Sulawesi, Maluku and West Nusa Tenggara together exhibit enhanced associations with rainfall, rainfall anomalies, humidity and the SOI. In contrast, East Kalimantan and Central Java show no significant associations with either humidity or the SOI. The results for this event support the suggestion of a distinction particularly between West and East Kalimantan and the remaining six provinces, but also with Central Java and Aceh at times behaving quite differently.

Table 6 shows the $\mathrm{R}^{2}$, or percentage of variance in dengue/DHF incidence rates that is explained by the optimal non-ENSO, ENSO1 and ENSO2 models in each province. This table further demonstrates a distinction between certain provinces in the way the five climate variables vary in their explanatory power between the three 'periods'. West and East Kalimantan show little change between the non-ENSO and ENSOl models, with a decrease in the $\mathrm{R}^{2}$ value during ENSO2, especially in East Kalimantan. In Aceh and Central Java, the non-ENSO models explain the greatest amount of variance. This decreases markedly in the ENSO1 models and even further in the ENSO2 model for Aceh. In Central Java, the magnitude of the regular seasonal dengue/DHF incidence cycle (see Arcari et al., 2007) increased during the ENSO2 event, which is reflected in the higher $\mathrm{R}^{2}$ at this time relative to the ENSOl model. The remaining four provinces, Jakarta, Central Sulawsi, Maluku and West Nusa Tenggara, all demonstrate a dramatic increase in the explanatory power of the models during ENSO2 as compared with the other provinces. Central Sulawsi, Maluku and West Nusa Tenggara have by far the highest $\mathrm{R}^{2}$ values of the three models, while in Jakarta, as in Central Java, the non-ENSO model explains the most variance, with only a minor decrease for ENSO2 and a more significant decrease for ENSOl.

The previous division of these eight provinces into three groups based on the nonENSO multiple regression analyses appears to be supported by the results of the ENSO analyses below.

Central Sulawesi, Maluku, West Nusa Tenggara and Jakarta. The second ENSO event had a markedly more dramatic association with increased dengue/DHF incidence than the

Table 6. Percentage of $\mathrm{R}^{2}$, or variance in dengue/DHF incidence rates explained by the optimal non-ENSO, ENSO1 and ENSO2 regression models in each province.

\begin{tabular}{lrrr}
\hline Province & Non-ENSO & ENSO1 & ENSO2 \\
\hline West Kalimantan & $15.9 \%$ & $15.7 \%$ & $12.9 \%$ \\
East Kalimantan & $15.3 \%$ & $12.2 \%$ & $6.3 \%$ \\
Central Java & $17.8 \%$ & $8.4 \%$ & $13.2 \%$ \\
Aceh & $14.4 \%$ & $7.3 \%$ & $4.4 \%$ \\
Jakarta & $24.5 \%$ & $13.1 \%$ & $21.3 \%$ \\
Central Sulawesi & $19.2 \%$ & $11.6 \%$ & $26.7 \%$ \\
Maluku & $20.5 \%$ & $9.6 \%$ & $32.2 \%$ \\
West Nusa Tenggara & $23.1 \%$ & $6.8 \%$ & $38.8 \%$ \\
\hline
\end{tabular}


first event. In each province, the major 10-year epidemic occurs between January and September 1998. Associations with at least four of the five climate variables are enhanced during the second event. The variable temperature explains the greatest amount of overall variance in dengue/DHF incidence in these provinces. Associations with rainfall are predominantly positive.

Aceh and Central Java. The associations between dengue/DHF incidence and the climate variables are little altered by either ENSO event. The major epidemics in both provinces occur outside of both ENSO periods. The variable rainfall explains the greatest amount of overall variance in dengue/DHF incidence. Associations with rainfall are again predominantly positive.

West and East Kalimantan. There is again little difference in the associations between dengue/DHF incidence and the climate variables during both ENSO events as compared with all other times. The major epidemics in both provinces occur outside of both ENSO events. Associations with rainfall are consistently negative. Most of the overall variance in dengue/DHF incidence is explained by temperature.

These groups were colour-coded and mapped (Figure 4). Additional provincial attributes appear in the accompanying boxes. Indonesia's remaining 19 provinces were similarly categorized based solely on their characteristic patterns of dengue/DHF incidence. This categorization provides a preliminary indication of the most likely climatic associations in each province and thus the probable nature of local dengue/DHF transmission dynamics.

\section{Discussion}

Based on this provincial analysis, it appears that regions like West Nusa Tenggara, Central Sulawesi, Maluku, Jakarta whose rainfall regimes are significantly altered by certain ENSO events, as seen especially during the 1997/98 event, are more inclined to experience intense epidemic activity specifically at these times. In contrast, regions with a strong seasonal rainfall signal, less dramatically altered by ENSO events, exhibit a pattern of dengue/DHF incidence more synchronous either with the pattern of seasonal rainfall, like in Aceh, Central Java, or with other factors not apparent from this study, like in West and East Kalimantan. Jakarta exhibits characteristics of both seasonality and epidemic activity related to the ENSO2 event. Thus, there appears to be a connection between the regional rainfall regime, its susceptibility to alteration under certain types of ENSO event and the pattern of provincial dengue/DHF incidence in terms of timing and possibly also intensity. This result supports findings by Vu et al. (2014) in Vietnam, where the authors observed considerable provincial variations in weather-dengue associations leading them to recommend local rather than national-level prevention strategies. It also supports the proposal by Hales et al. (2003) that climate extremes are more critical for human health than changes in means. Following Aiken et al. (1980), study results suggest that the impact of increased rainfall on dengue/DHF incidence is enhanced following a period of rainfall deficit associated with the El Nino phase, a pattern observed also by Kolivras (2010) in Hawaii.

Contrary to WHO (2004) and Henderson (Blood Weekly, 1998), this study finds too many regional differences to support the proposal that dengue epidemics in Indonesia follow a five-year periodicity. As Morin et al. (2013: 1270) have found, there are too many 
nonlinearities and feedbacks in the climate/disease system to rely on one predictor, added to which are a host of human factors, such as 'behaviour, immunity, and socioeconomic influences' that contribute to the complexity of disease dynamics. Nevertheless, as only two ENSO events are included in this study, it is not considered a sufficient basis on which to comment definitively. The results do however support the assertion by Halstead (2008) that ENSO does not affect the periodicity of dengue activity in this region. Rather, ENSO events can affect the intensity of incidence, whether the underlying pattern is seasonal, epidemic or endemic, and depending on other environmental, social, virological and immunological factors. A study of dengue diffusion in Brazil (Barcellos \& Lowe, 2014) reached similar conclusions, whereby the authors identified areas of 'permanent' (endemic) and 'discontinuous' (seasonal or epidemic) transmission corresponding strictly to climatic zones, leading them to similarly identify three climate categories associated with different dengue transmission regimes. Importantly, the authors also note that their study highlights the need to revise climate-based models and maps under conditions of ongoing climate variability, as well as changing socio-economic conditions.

More research is needed on the magnitude of the impact on disease dynamics of even slight changes in the duration and intensity of climate variations. In addition, the potential for the concurrence of several high-risk factors for increased dengue/DHF incidence ought to be understood within the context of single factor studies by integrating multidisciplinary data such as climate, topography, land use, virology, entomology, demographics and particularly socio-economic and cultural factors, which are being increasingly recognized as key factors in dengue transmission (Colon-Gonzalez et al., 2013; Barcellos $\delta$ Lowe, 2014; Nadeeka et al., 2014). Such additional 'layers' may help explain provincial variations in Figure 4 that seem inconsistent with geographic and climatic zoning.

\section{Conclusion}

Between 12.9 per cent and 24.5 per cent of the variance in provincial dengue/DHF incidence can be explained by a combination of two or three climate variables in each of the eight selected provinces ( $p<0.01$ to 0.1 ). During the 1997/98 ENSO event, the explained variance increased by between 7 per cent and 15 per cent in those provinces whose climate regimes were most affected by this event. Rainfall is the principal climatic agent affecting the geographical distribution and temporal pattern of dengue/DHF incidence, while temperature plays a critical role in outbreak intensity (Arcari et al., 2007).

This study has demonstrated that indicators of ENSO such as the SOI may be effective in the forecast of potential dengue/DHF incidence and distribution in Indonesia. However, this finding is conditional on further research to determine the relationship between SOI values and ENSO events of different lengths, intensities and climatic outcomes. In addition, before the SOI or other indicators of ENSO can be used to assist in the prediction of dengue/DHF incidence, it is necessary to acquire knowledge and understanding of regional-scale factors that influence the varying impact of these events on dengue/DHF dynamics. This knowledge relates to the following.

1. The underlying pattern of regional dengue/DHF incidence-whether endemic, epidemic, seasonal, or a combination. This pattern will indicate if the environment is likely to be favourable or unfavourable for year round transmission.

2. The seeming triggers for increased incidence-rainfall, drought or increased temperatures, and the sequence and/or combination of these factors.

3. The pre-existing ecological, environmental and societal conditions that dictate how these triggers operate, and the duration they take to result in increased dengue/DHF incidence. 
Combined with the knowledge of how an extreme event like ENSO is likely to affect different regions, this enhanced understanding will enable those areas most at risk to be identified and appropriate timely mitigating action to be taken, to avert a major outbreak.

The study of ENSO events in relation to dengue incidence has the potential to deliver greater understanding of the links between this disease and climate, and of the ways different regions are likely to be affected by subsequent events. The study will help governments and health authorities be better prepared to mitigate the impact of ENSO events and may contribute to a more informed assessment of how future climate scenarios are likely to affect broader dengue distribution and intensity. This capacity would appear to be an increasingly urgent task given that various authors and research institutions agree that under global warming, these ENSO events and other patterns of climate variability are occurring with greater intensity and frequency, and will continue to do so.

\section{Endnote}

1. In the ENSO event regression analyses, each climate variable is modelled individually. Hence the change in incidence rates associated with a one unit change in the variable is often greater than in the all-in-one analyses, where all five variables are contained in one model.

\section{References}

Asian Development Bank (1994) Climate change in Asia: Indonesia. Report. ADB, Manila.

Aiken SR, Frost DB, Leigh CH (1980) DHF and rainfall in peninsular Malaysia. Social and Scientific Medicine 14D, 307-16.

Amarakoon AMD, Chen AA, Rawlins SC, Taylor MA (2007) Dengue epidemics - its association with precipitation and temperature, and its seasonality in some Caribbean countries. Available at: http://chiex.net/documents/CHRS-2004_submitted.doc (accessed 8 June 2009).

Arcari P et al. (2007) Regional variability in relationships between climate and dengue/DHF in Indonesia. Singapore Journal of Tropical Geography 28 (3), 251-72.

Arndt D (2015) How will El Nino affect 2015's placement among warmest years on record? ClimateWatch Magazine, Climate.gov, NOAA. 4 June. Available at: www.climate.gov/newsfeatures/blogs/beyond-data/how-will-el-niño-affect-2015's-placement-among-warmest-yearsrecord (accessed 5 December 2016).

Australian Bureau of Meteorology (n.d.) Homepage. Available at: http://www.bom.gov.au/climate/ current/soi2.shtml/ (accessed 5 December 2016).

Barcellos C, Lowe R (2014) Expansion of the dengue transmission area in Brazil: the role of climate and cities. Tropical Medicine and International Health 19 (2), 159-68.

Blood Weekly (1998) Indonesia, public health dengue epidemic adds to economic burden. Henderson C, 11 May. Available at: www.hartford-hwp.com/archives/54b/091.html (accessed 5 December 2016).

Chiew FHS, Piechota TC, Dracup JA, McMahon TA (1998) El Nino/Southern Oscillation and Australian rainfall, streamflow and drought: links and potential for forecasting. Journal of Hydrology 204, 138-49.

Colon-Gonzalez FJ, Fezzi C, Lake IR, Hunter PR (2013) The effects of weather and climate change on dengue. PLoS Neglected tropical Diseases 7 (11), e2503.

Corwin AL, Larasati RP, Bangs MJ et al. (2001) Epidemic dengue transmission in southern Sumatra, Indonesia. Transactions of the Royal Society of Tropical Medicine and Hygiene 95, 257-65.

De Vaus DA (2002) Analysing Social Science Data. SAGE, London.

Epstein PR (1999) Extreme weather events: the health and economic consequences of the 1997/98 El Nino and La Nina. The Centre for Health and the Global Environment. Harvard Medical School. Report. Available at: www.chgeharvard.org/sites/default/files/Extremeweatherreport. pdf (accessed 5 December 2016). 
Gagnon AS, Bush ABG, Smoyer-Tomic KE (2001) Dengue epidemics and the El Nino Southern Oscillation. Climate Research 19, 35-43.

Glantz MH (1996) Currents of Change. El Nino's Impact on Climate and Society. Cambridge University Press, Cambridge.

Gubler DJ (1998) Dengue and dengue hemorrhagic fever. Clinical Microbiology Reviews 11 (3), 480-96.

Gubler DJ, Meltzer M (1999) Impact of dengue/dengue hemorrhagic fever on the developing world. Advances in Virus Research 53, 35-70.

Gujarati DN (1995) Basic Econometrics. McGraw-Hill, New York.

Hales S, Weinstein P, Woodward A (1996) Dengue fever epidemics in the South Pacific: driven by El Nino Southern Oscillation? The Lancet 348, 1664-65.

Hales S, Edwards SJ, Kovats RS (2003) Impacts on health of climate extremes. In McMichael AJ, Campbell-Lendrum DH, Corvalan CF, Ebi Kl, Githeko A, Scheraga JD, Woodward A (eds) Climate Change and Human Health - Risks And Responses, 79-102. World Health Organization, Geneva. Available at: www.who.int/globalchange/publications/cchhbook/en/ (accessed 5 December 2016).

Halstead SB (2008) Dengue virus-mosquito interactions. Annual Review of Entomology 53, $273-91$.

Hurtado-Diaz M, Riojas-Rodriguez H, Rothenberg SJ, Gomez-Dantes H, Cifuentes E (2007) Short communications: impact of climate variability on the incidence of dengue in Mexico. Tropical Medicine and International Health 12 (11), 1327-37.

$\mathrm{Hu}$ W, McMichael AJ, Tong S (2004) El Nino Southern Oscillation and the transmission of hepatitis A virus in Australia. The Medical Journal of Australia 180 (9), 487-88.

Intergovernmental Panel on Climate Change (2001) Climate Change 2001: Impacts, Adaptation and Vulnerability. Intergovernmental Panel on Climate Change. Third Assessment Report. WMO and UNEP, Geneva.

Karyanti MR, Uiterwaal CSPM, Kusriastuti R et al. (2014) The changing incidence of dengue haemorrhagic fever in Indonesia: a 45-year registry-based analysis. BMC Infectious Diseases 14 (412), 1-7.

Kamaruddin D, Sungkar S (2013) The trend of dengue hemorrhagic fever cases in central Jakarta 2008-2010. eJurnal Kedokteran Indonesia 1(1), 15-22.

Keating J (2001) An investigation into the cyclical incidence of dengue fever. Social Science and Medicine 53, 1587-97.

Kiladis GN, van Loon H (1988) The Southern Oscillation. Part VII: meteorological anomalies over the Indian and Pacific sectors associated with the extremes of the oscillation. Monthly Weather Review 116, 120-36.

Kirono D (2000) Indonesian Rainfall Variability, Links to ENSO and Agricultural Impacts (PhD Dissertation). School of Geography and Environmental Science, Monash University, Melbourne, Australia.

Kirono D, Tapper N (1999a) ENSO rainfall variability and impacts on crop production in Indonesia. Physical Geography 20 (6), 508-19

Kirono D, Tapper N (1999b) Documenting Indonesian rainfall in the 1997/98 El Nino Event. Physical Geography 20 (5), 422-35.

Kolivras KN (2010) Changes in dengue risk potential in Hawaii, USA, due to climate variability and change. Climate Research 42, 1-1.

Kovats S, Bouma MJ, Hajat S, Worrall E, Haines A (2003) El Nino and health. The Lancet 362 (9394), $1481-9$.

Kuipers JC (1993) The Society and its environment. In Frederick WH, Worden RL (eds) IndonesiaA Country Study, 72-135. Federal Research Division, Library of Congress, Washington DC.

Marlier M, DeFries RS, Voulgarakis A et al. (2013) Nature Climate Change 3 (February), 131-36.

McMichael AJ, Haines JA, Rudolf, S, Kovats S (1996) Climate Change and Human Health: An Assessment. WHO, UNEP, WMO, Geneva.

Monath TP (1995) Dengue: the risk to developed and developing countries. In Roizman B (ed) Infectious Diseases in an Age of Change: The Impact of Human Ecology and Behaviour on Disease Transmission, 43-58. National Academy Press, Washington DC. 
Morin CW, Comrie AC, Ernst K (2013) Climate and dengue transmission: evidence and implications. Environmental Health Perspectives 121 (11-12), 1264-72.

Murray NEA, Quam MB, Wilder-Smith A (2013) Epidemiology of dengue: past, present and future prospects. Clinical Epidemiology 5, 299-309.

Nadeeka PVJ, Gunathilaka PADHN, Amarasinghe LD (2014) Geographic, Economic and sociocultural factors which defining the risk of dengue transmission in Kelaniya, Sri Lanka. Journal of Experimental Biology and Agricultural Sciences 2 (2), 157-64.

NASA (2016) 2016 climate trends continue to break records. Lynch P, 20 July. Available at: Www.nasa.gov/feature/goddard/2016/climate-trends-continue-to-break-records (accessed 5 December 2016).

NOAA (2006) El Nino, La Nina, and ENSO. National Weather Service. Available at: www.nws.noaa. gov/os/brochures/climate/El_NinoPublic.pdf (accessed 5 December 2016).

NOAA (2016) June 2016 ENSO discussion: The new neutral. Becker, E., June 9. Available at: https:// Www.climate.gov/news-features/blogs/enso/june-enso-discussion-new-neutral (accessed 5 December 2016).

Poveda G, Graham NE, Epstein PR et al. (2000) Climate and ENSO variability associated with vectorborne diseases in Colombia. In Diaz HF, Markgraf V (eds) El Nino and the Southern Oscillation: Multiscale Variability and Global and Regional Impacts, 183-204. Cambridge University Press, Cambridge.

Rodhain F, Rosen L (1997) Mosquito vectors and dengue virus-vector relationships. In Gubler DJ, Kuno G (eds) Dengue and Dengue Haemorrhagic Fever, 45-60. CAB International, London.

Ropelewski CF, Halpert MS (1987) Global and regional scale precipitation patterns associated with the El Nino/Southern Oscillation. Monthly Weather Review 115, 1606-26.

The Weather Network (2015) El Nino 2015 could be one of the strongest on record. Sutherland S, August 13. Available at: www.theweathernetwork.com/news/articles/whats-up-in-climate-change-el-nino-2015-could-rival-strongest-events-on-record-noaa/55667/ (accessed 5 December 2016).

Trenberth KE (1997) The definition of El Nino. Bulletin of the American Meteorological Association 78 (12), 2771-77.

Trenberth KE, Hoar TJ (1996) The 1990-1995 El Nino Southern Oscillation event: longest on record. Geophysical Research Letters 23 (1), 57-60.

Vu HH, Okumura J, Hashizume M, Tran DN, Yamamoto T (2014) Regional differences in the growing incidence of dengue fever in Vietnam explained by weather variability. Tropical Medicine and Health 42 (1), 25-33.

World Health Organization (1993) Monograph on Dengue/Dengue Haemorrhagic Fever. No. 22. Regional Publication. SEARO. WHO, Geneva.

WHO (2004) Dengue fever in Indonesia-update 4. Available at: www.who.int/csr/don/ 2004_05_11a/en/ (accessed 5 December 2016).

WHO (2009) Dengue: guidelines for diagnosis, treatment, prevention and control. WHO, Geneva. Available at: www.who.int/tdr/publications/documents/dengue-diagnosis.pdf?ua=1 (accessed 5 December 2016).

Woodruff R, Guest C (2000) Teleconnections of the El Nino phenomenon. In Grove RH, Chappell J (eds) EL Nino-History and Crisis. Studies from the Asia-Pacific Region, 89-108. White Horse Press, Cambridge.

\section{Supporting information}

Additional Supporting Information may be found online in the supporting information tab for this article:

Box Summary of Methodology behind Dummy Regression Analyses 